\title{
Strength of Evidence of Electronic Media (Teleconference) In The Criminal Justice System
}

\author{
Muslim Mamulai ${ }^{1}$, Hardianto Djanggih ${ }^{2}$ Mirnawanti Wahab ${ }^{3}$ \\ ${ }^{1}$ Faculty of Law, University of Muhammadiyah Palu \\ ${ }^{2}$ Faculty of Law, University of Tompotika Luwuk \\ ${ }^{3}$ Sekolah Tinggi IImu Ekonomi AMKOP Makasar \\ hardianto djanggih@yahoo.co.id
}

\begin{abstract}
The strength of the evidence of Electronic Media (teleconference) in the process of proving a criminal case according to the Criminal, specify a limited manner valid evidence and procedures for the use of that evidence thus have legal power of proof. Proof via electronic media (teleconference) regulates the judge / magistrate constitutional obligation to seek and find the truth so that the material taken into consideration for the judges in deciding a case. Implementation of evidence through electronic media in a criminal act, should the judge may use the priority when it will use the values of the basic purpose of the law (justice, expediency and certainty) to accommodate the evidence through electronic media in examining the crime of existing.
\end{abstract}

Keywords: Strength of Evidence, Teleconference, Criminal Justice

\section{preliminary}

Constitution of the Republic of Indonesia Year 1945 (Constitution NRI 1945) (amendment) Article 1 (3), "Indonesia is a country of law". ${ }^{1}$ Law is pemcerminan of prevailing values in society, this means that the values of society change, so should hukumpun follow these changes. ${ }^{2}$ Perlegal developments in Indonesia, especially in the formal criminal law with the

\footnotetext{
${ }^{1}$ Dayanto, "Rekonstruksi Paradigma Pembagunan Negara Hukum Indonesia Berbasis Pancasila", Jurnal Dinamika Hukum, Vol. 13, No. 3, 2013. p.498 cite to Hardianto Djanggih and Kamri Ahmad, The Effectiveness of Indonesian National Police Function on Banggai Regency Police Investigation (Investigation Case Year 2008-2016, Jurnal Dinamika Hukum, Vol. 17, No. 2, 2017, p.152.

2 Tri Wahyu Widiastuti, Peranan Perubahan Sosial Terhadap Macam Alat Bukti Dalam RUU KUHAP, Jurnal Wacana Hukum, Vol.8, No.1, 2009, p.14
} 
establishment of Law No. 8 of 1981 on the Code of Criminal Procedure, is one progressive attitude to immediately abolish colonial law as soon as possible. With the enactment of the Criminal Procedure Code, plainly has caused fundamental changes, both conceptually and in implementation of the procedures for the settlement of a criminal case in Indonesia, namely a change in the way of thinking that resulted in a change in attitude and way of acting officials or law enforcement as a whole.

Polarization verification activities if the threads drawn wider dimension will lead to the rules of evidence in it. Examined from the perspective of criminal procedural law rules of evidence exist, are born, grow and evolve in order to draw a conclusion for a judge in a court to declare the defendant is proven or not committed any criminal act as indicted by the public prosecutor in the indictment, and finally poured judges in criminal order to the defendant. Sentences by judges through legal dimensions of this evidence, are oriented to the provisions of Article 183 Criminal Procedure Code that specifies that: ${ }^{3}$ The strength of evidence alone, according to Kamri Ahmad ${ }^{4}$ substantive is "authentic evidence containing formal nature of truth and material. Formal truth is truth guided by the Act, while the material truth is the truth according to what as fact ".

On past evidence admissibility in court is limited to the evidence that was material, that is the evidence that can be seen and touched. In Indonesia, the evidence is allowed and legitimate under Article 184 paragraph (1) of Law No. 8 of 1981 on Criminal Proceedings (Criminal Code), namely evidence statements of witnesses, expert testimony, letters, instructions and testimony of the

\footnotetext{
${ }^{3}$ Arbiyanto Takasihaeng, Praktik Peradilan Dalam Penerapan Alat-alat Bukti Menurut KUHAP, Jurnal Lex Crimen, Vol.2, No.3, 2013. p.124

${ }^{4}$ Kamri Ahmad, Prospektif Hukum Pidana dalam Pandangan Filosofi, in Esmi Warasih Pujirahayu, Pemikiran Hukum Spiritual Pluralistik, Sisi Lain Hukum yang Terlupakan, Tafa Media, Yogy akarta, 2016, p.394-395
} 
defendant. The entire evidence mentioned in the Criminal Procedure Code does not accommodate electronic evidence. ${ }^{5}$

Court via teleconference is not regulated in the Criminal Code, resulting in a problem of legality is highly interpretive. But before going any further about the teleconference utilize as evidence in the trial, various ideas and reviews as well as the frame of waking seems to have started a conical that the teleconference closest correlation with the evidence of witnesses.

Teleconference justice been done in the case of Bali bombing by defendants Ali gufron as Muhklas held with media teleconference from min bin wan wan testimony of Malaysia. Reasons to use teleconference on the practical nature of the case, this is because the witness did not need to come to Bali just to testify, so as to shorten the time and cost saving. Counter parties to the presence of the media teleconference, said that by testifying via media teleconference considered invalid because it was not present at the hearing the truth, and the provisions on the media is not expressly provided in the Code of Criminal Procedure. ${ }^{6}$

\section{Discussion}

Electronic systems used to explain the existence of the information system is the application of information technology-based telecommunications network and electronic media, the design work, process, analyze, display, and transmit or disseminate electronic information. Technical information systems and management is actually the embodiment of the application of information technology products in a form of organization and management in accordance

\footnotetext{
${ }^{5}$ Syabatul Hamdi, et.all, Bukti Elektronik Dalam Sistem Pembuktian Pidana, Jurnal IImu Hukum, Vol.1, No.4, 2013, p.25

${ }^{6}$ Putu Elik Sulistiyawati dan I Ketut Sujana, Pemanfaatan Telekonfren Sebagai Alat Bukti Bantu Pembuktian Dalam Sistem Peradilan Pidana, Jurnal Kertha Wicara, Vol.2, No.1, 2013, p.2
} 
with the characteristics and needs of the organization in accordance with the purpose intended. ${ }^{7}$

Technology teleconference serving detailed picture and sound quality are clearly without disturbance (noise), allowing the judge to know directly the eyes, facial features, as well as body language (gestures) indicated by a pre-trial. Thus in principle the presence of a person in court referred physically present can also be fulfilled by using teleconference technology.

Teleconference is right to replace the presence of a witness in court virtually. But need attention also in terms of time allocation request information from witnesses, it is important for a narrow and limited time will greatly affect the quality of the completeness and depth of information obtained from witnesses. If the issue is not time allocation to get the complete solution, then the entire effort futile virtually presenting witnesses in advance of a trial for shallow information and information required.

Verification system in the Code of Criminal Procedure (Criminal Procedure Code), the evidence is very limited and there is no regulation regarding electronic evidence, if any, are limited and it can not stand alone. ${ }^{8}$ The strength of evidence teleconferencing and other electronic media in the process of proving a criminal case according to the Criminal Code, it is emphasized once again that the Criminal Code has specified a limited manner valid evidence and procedures for the use of that evidence thus have legal power of proof.

Valid evidence pursuant to Article 184 Criminal Procedure Code is the testimony of witnesses, expert testimony, letters, instructions and testimony of the defendant. Legal evidence in the Criminal Code, in addition to the term

\footnotetext{
${ }^{7}$ Refly Aditya Mamitoho, Penggunaan Alat Bukti Elektronik Dalam Pemeriksaan Perkara Perdata, Jurnal Lex Ex Societatis, Vol.2, No.1, 2014, p.66

8 Yudhistira, et.all, Kekuatan Surat Elektronik Sebagai Alat Bukti Dalam Persidangan Dintinjau Dari Hukum Acara Pidana, Jurnal Kertha Wicara, Vo.1, No.1 2012, p.2
} 
evidence, also known as the term of evidence. Evidence not mentioned included into one legal evidence. In other words, the evidence is not evidence. ${ }^{9}$

Seliteral way, the term teleconference can be interpreted as "a conference or a meeting at a distance"; or it can also be interpreted as "face-toface live broadcast at a distance", which happen to be inseparable from the use of telecommunication systems as a result of globalization and the development of communication technology today.

Mateleconference had stabbed him in the trial of criminal cases in Indonesia, showed that the laws are not silent but growing with the development of science and technology. This statement is corroborated by the statement Sunaryati Hartono ${ }^{10}$ That development in the legal field will include:

1. To perfect (make something better),

2. Changing in order to become better and more modern,

3. To fetch something that did not previously exist, or

4. Obviate something that is contained in the old system, because it is not necessary and does not fit with the new system.

The teleconference during the trial, as a breakthrough should not create the impression of discrimination in terms of expediency normative or sociological. If this fact reflects the shortcomings of the Criminal Procedure Code in accommodating the expectations of the justice seekers (justiabelen), required an assessment back to the Criminal Code in order to realize constituendum juice as expected.

In the framework of realizing substantial justice is, indeed Article 5 (1) of Law Number 48 Year 2009 concerning Judicial Authority has explained that, "Justice and Constitutional Justice shall explore, and understand the legal

9 Daniel Saputra, peggunaan Evidence In Evidence of Electronic Information Narcotic Crime In Aceh, Dynamics Law Journal, Vol.3, No.2, 2015, p.27

${ }^{10}$ C.F.G Sunaryati Hartono, Hukum Ekonomi Pembangunan Indonesia, Binacipta, Bandung, 1982, p.8. 
values and sense of justice in the society ". Nevertheless, it should be understood and understood that the above only illustrates an obligation, which is not the same as government authority (the President) and the Parliament as mandated by Article 5 (1) and Article 20 (1) UUDRI 45 Amendment IV within the framework of the task of regulation lagalitas accordance with the principles that have expansion as a condition of a written understanding (lex scripta), must be interpreted as what is read (lex stricta) and interpretations (lex certa).

It's meaning ability to judge here only a limited ability to commune laws that live in the community, so expect the judge to give a verdict in accordance with the law in order to meet the desires of those seeking justice. And if Article 5 (1) of Law Number 48 Year 2009 concerning Judicial Authority is carried out by the judge in the judicial practice will result in a jurisprudence (Judge Made Law).

The types teleconference that was used in the trial of criminal cases, is a kind of teleconference using wire system or telephon (just to hear his voice, as in the case of human rights violations in East Timor), and the teleconference by using an optical system (audio-visual, such as in the case of Abu Bakar Ba'asyir).

In some developed countries, especially in Britain, the judicial system continues applied alongside conventional examination procedure trial new form (modern). New forms in question, as described by M. Yahya Harahap ${ }^{11}$ there is teleconference, whose shape can be:

(a) Behind a screen or called To give evidence from behind a screen; witnesses to testify (checked behind the scenes), so that:

i. The witness did not deal directly with the defendant at the time the witness testified,

\footnotetext{
${ }^{11}$ M. Yahya Harahap, 2006, Pembahasan Permasalahan dan Penerapan KUHAP Pemeriksaan Sidang Pengadilan, Banding, Kasasi, dan Peninjauan Kembali: Edisi Kedua, Sinar Grafika, Jakarta, p.120
} 
ii. With conditions, the defendant must be heard fully testimony of witnesses.

Ordinances behind a screen, especially applied in the case investigation "rape" (rape) and "sexual abuse" (sexual abuse) to the "child".

The aim is to avoid the witness or minor child of a "trauma", as well as to avoid the "ordeal" for witnesses when dealing directly with the defendant at trial.

(b) By a live television link: Witness testimony given via "direct view" which is connected to the courtroom:

i. Indirect witness in person and face to face with the accused present in the courtroom,

ii. Witnesses were somewhere else, but at the time of giving information to do with systems and techniques by live television link in the courtroom,

iii. Thus the face and voice of witnesses when giving testimony can be seen and heard the accused "on the screen".

(c) Videotape record or "camera": witness testimony videotaped record or camera (the hearing may be held in camera or videotape record), and the record is what was shown in the courtroom.

The teleconference using, setting about proving this teleconference is narrowly regulated under Article 9 paragraph (3) of the Constitution of the Republic of Indonesia Number 13 Year 2006 on the protection of witnesses and victims. ${ }^{12}$ provisions can be used as a basis to measure the strength and assessment of evidence, among other things by observing and reviewing the provisions contained in Article 183 to Article 189 Criminal Procedure Code in conjunction with Article 3 of the Criminal Procedure Code and Article 284 (2)

12 Swindy A.J.T, Kesaksian Saksi Melalui Teleconference Dalam Persidangan Pengadilan, Jurnal Lex Ex Societatis, Vol.2, No.8, 2014, p.61 
Criminal Procedure Code; Article 5 (1) and Article 10 paragraph (1) of Law Number 48 Year 2009 concerning Judicial Authority.

Talking on setting up a teleconference and other electronic media, it is the setting here is referring to an arrangement made in writing, clearly and unequivocally (lex scripta, lex certa, lex stricta); so legitimately (legitimate), legislation in the context of the law as a system both horizontally and vertically should be a legislative product. This means that the words of the written law or the law here only laws in the formal sense or law made by the Government or Parliament without ignoring principles of legality.

A pictures quern teleconference, de facto as in the articles of the Criminal Procedure Code above, no or not found any of the clauses governing the teleconference models that can be used as a means of delivering information from witnesses in proof system. That is, that under Article 185 paragraph (1) Criminal Code explains that "witness testimony as evidence is what the witness stated in court". Likewise in other regulations related particularly Law No. 36 Year 1999 on Telecommunication to Government Regulation No. 52 of 2000 on Telecommunications, do not set explicitly on the teleconference, but only set the technical and operational use of telecommunications networks, which of them can be used for the provision of teleconference in various purposes.

In certain laws that regulate specific provisions of criminal procedure in connection with the case raised in this article, such as Law No. 15 of 2003 on Stipulation of Government Regulation in Lieu of Law No. 1 of 2002 on Combating Terrorism, Become Law Law, and Law No. 20 of 2001 on the Amendment of Act No. 31 of 1999 on Corruption Eradication, appropriate application of the principle of lex de Rogat lex generalis, it also does not regulate the provision of witness testimony that can be delivered via teleconference. That there is that in these laws regulate provisions concerning 
the expansion of evidence that it is set in the Criminal Procedure Code. Article 26 A of Law No. 20 of 2001 Amendment Act No. 31 of 1999 on Corruption Eradication organize electronic evidence as an extension of the evidence in the instructions as described in Section 188 subsection (2) Criminal Procedure Code, that "evidence User as referred to in Article 188 paragraph (2) Criminal Procedure Code, can also be obtained via electronic evidence ". Likewise in Article 27 of Law No. 15 of 2003 Stipulation of Government Regulation in Lieu of Law No. 1 Year 2002 on Combating Criminal Acts of Terrorism, Being Act, recognizes the electronic evidence in addition to the evidence that was set inCriminal Procedure Code. Clearly, that teleconference used to hear witness testimony BJ Habibie of Hamburg-Germany related to a corruption case (case Bulog) is not as electronic evidence as referred to in Article 26 A of Law No. 20 of 2001 Amendment No. 31 year 1999 on Corruption Eradication.

teleconference in the case Abu Bakar Ba'asyir (via Case Number: 547 / Pid.B / 2003 / PNJkt.Pst) that process eventually show purely based on the Criminal Code is not based on Law Number 15 Year 2003 regarding Stipulation of Government Regulation in Lieu of Law No. 1 Year 2002 on Combating Criminal Acts of Terrorism, Being Act, means of proof should be guided by the Code of Criminal Procedure Article 184 in conjunction with Article 183 Criminal Procedure Code and Article 185 paragraph (1) Criminal Procedure Code.

To measure the value and strength of evidence (the degree of evidence) witness testimony as valid evidence by the Criminal Code, are:

1. Saction must take an oath or pledge

2. Descriptions witness is what the witness see, hear his own, and his own experience (not testimonials de auditu).

Similarly, the criminal act of terrorism, as defined in Article 27 of Law Number 15 Year 2003 regarding Stipulation of Government Regulation in Lieu 
of Law No. 1 Year 2002 on Combating Criminal Acts of Terrorism, Being Act, that other evidence as evidence electronic.

1. Descriptions witness should be given trial court

2. Descriptions one witness alone is not sufficient (one witness is not a witness / unus testis nullus testis).

The law on the judicial power also warned that what judges consider in judicial practice, should not deviate from the principles and rules of criminal law (either material or formal) ${ }^{13}$,

Properly accountingthrough electronic media and the judicial authorities, one of which regulates the judge / magistrate constitutional obligation to seek and find the truth so that the material taken into consideration for the judges in deciding a case. It should be considered prior to the evidentiary stage is the search for evidence or evidence that there may be (found). Evidence is the stuff on which the offense is done (the object of the offense) and goods safely offense is done, the tool used to commit the offense ..., as well as evidence of the offense is the result of ..., goods that have a direct relationship with the criminal offense ${ }^{14}$,

Hit the mark tools used in electronic media, Sahuri Lasmadi ${ }^{15}$ said to do a test of the validity of the computer system. Based on the results of preliminary examination of the validity of a computer system (either a certificate or other certificate signed by an authorized officer) will become a guarantee for others who have done an activity using the computer system. All data and information generated by the computer certified to be accountable. If in the future there is a crime, then the electronic evidence contained in the hard disk, diskette or print

${ }^{13}$ H. Pontang Moerad B.M.,Pembentukan Hukum Melalui Putusan Pengadilan Dalam Perkara Pidana, Alumni, Bandung, p.53

14 Edmon Makarim, Pengantar Hukum Telematika, 2005, Jakarta : Raja Grafindo Persada, p. 479 Hukum, 2014 
out, has the strength of evidence is perfect. Certificate or certificate of operation of such a system, relied upon that the computer equipment is safe and reliable.

$\mathrm{KTI}$ electronics consist of 3 kinds $^{16}$, that is:

1. Real evidence,

$\mathrm{KTI}$ electronic meant here is the result of direct recording of an activity electronically, the results of counting or analysis by a computer system that has been working in accordance with the procedures of software used for the processing of data or information, recording log data from a server on the Internet, or also may take the form of copies (receipt) of a piece of equipment such as recording cameras using sensors. Real evidence can be used in a lot of possibilities. Let's take the example of a bank conducted a transaction with a client on a percentage of the tax cuts automatically on the account, and every time the customer can check it, then cutting (calculation) is included in the estate tax evidence;

2. Hearsay evidence.

Later second is evidence Hearsay, where documents or records that are the result of processing by using a computer, all of which are copies of an information on paper. The computer data processing does not take place automatically but performed by humans. An example is in a transaction at the bank, a customer wanted to redeem a check at a bank, then the data listed above the check is validated by using a computer that is in the bank. Is it true that the signature is a signature of the account holder, account number, and identity, copies of checks after going through the validation process can be classified into Hearsay evidence.

\footnotetext{
${ }^{16}$ Naskah Akademik Rancangan Undang-Undang tentang Tanda Tangan Elektronik dan Transaksi Elektronik Lembaga Kajian Hukum Teknologi, Fakultas Hukum Universitas Indonesia (Ikht-fhui), Depok, 2001
} 


\section{Derived evidence,}

Dividing latter is a combination of both (real Hearsay evidence and evidence). The use of data or electronic messages as evidence in court sought whether there is a relationship between the two. For example, in a transaction at the bank, every day synchronization between the data transaction is a live recording of an activity of a transaction by using a computer with the activities of the parties (bank and its customers).

There are three things that can be used as a guide for the use of electronic evidence in a case that occurred in electronic transactions is ${ }^{17}$ :

1. A pattern (modus operandi) are relatively equal in committing a crime by using computers;

2. The existence of a rapprochement between one event with another event;

3. The reason for committing a crime

At last, it can be seen that the model or a way to establish through the electronic media as a means to convey information from witnesses jo. Article 185 paragraph (1) Criminal Procedure Code is the witness who must be physically delivered (in person) at the hearing. Rationally it should be interpreted as an attempt of the legislators in order that a solemn courtroom situation can shape psychological aspects of the witness in giving correct information and honest so that judges gain confidence in order to realize the material truth.

The other, a way to establish through the electronic media seem contrary to the principles that apply in criminal procedural law, especially the principle of "justice must be done quickly but simple and inexpensive; as well as free, fair and impartial (discriminatory) which in practice should be applied consistently in all levels of the judiciary.

17 Ibid. 
Of judicial power, explains: "..... that the judges themselves should remain free from the influence, except at the behest of law, the constitution, a decision that considers a healthy mind, legal precedent, and command the conscience of the judge's own" Electronic Verification is inseparable from formal requirements and material requirements specified in UU ITE. Regarding the formal and substantive requirements, Josua Sitompul ${ }^{18}$ states:

"Formal requirement set out in Article 5 paragraph (4) of the Act ITE, namely that information or Electronic Document is not a document or letter that legislation must be in written form. While the material requirements set out in Article 6, Article 15 and Article 16 of Law ITE, which is at the core of Information and Electronic Documents must be guaranteed their authenticity, integrity, and its availability. To ensure the fulfillment of the requirements of material is, in many ways it takes digital forensics ".

Marking evidence or electronic evidence can not be restricted or required designation through legislation. Most importantly, the evidence and the evidence depends on originality and authenticity in order of importance proving criminal cases, civil, administrative, or other fields of law. Due to the use of electronic technology is neutral, it could be evidence and turned into evidence dependent actions (criminal) that accompany it.

The electronic use for technology can not be blocked because of the development of information technology has reached all aspects of life. However, the use and target limited social etiquette which could result in an act of public reproach. Restrictions on evidence and electronic evidence by law contradicts with the principles in the criminal justice guaranteed by the constitution.

18 Josua Sitompul, 2012, Cyberspace, Cybercrimes, Cyberlaw : Tinjauan Aspek Hukum Pidana, Tatanusa, Jakarta, p 45 
Because, process justice often requires strong evidence and complete in order to ensure legal certainty based on the evidence that is required by law.

For the solution, in order to complement and enhance the purpose of Article 185 paragraph (1) Criminal Code under Article 3 in conjunction with the Criminal Procedure Code. Section 284 subsection (2) Criminal Procedure Code, should immediately set about the use of teleconference is. The general rationale, that Indonesia is a country where the law of de facto and de jure that:

(1) System state law in Indonesia prioritizes written law.

(2) Base and the rule of law (especially criminal formal criminal) applies is important and must be applied consistently, because the principles and rules of law that is the spirit of his life.

(3) The main pillars of the law (certainty, justice and expediency) Must be respected in order to prevent the collapse of the authority of the law.

(4) Base -principle contained in the principles of legality is an important and main principles for the legal certainty and certainty of justice.

(5) The purpose of the law on criminal procedure itself that implement process fair law or due process of law (which among other elements of proof, and carry out a fair trial or equal justice) to seek and realize the material truth.

hit the marki testimony by using the teleconference, actually have gained recognition and have been arranged in Law No. 13 of 2006 on Protection of Witnesses Victims as amended by Act No. 31 of 2014 on the Amendment of Law No. 13 of 2006 on Protection of Witnesses Victims of set. Article 9 paragraph (3) of Law No. 13 of 2006 as amended by Act No. 31 of 2014 on the Amendment of Law No. 13 of 2006 on Protection of Witnesses Victims, reads "Saksi and / or victim referred to in subsection (1) may also hear testimony directly through electronic means, assisted by a competent authority ". The meaning of words through electronic means as the sound of the chapter, in our 
opinion is a recognition of the teleconference in terms of evidence through electronic media.

Proof via electronic media, Munir Fuady ${ }^{19}$ said as demonstrative evidence. The evidence which does not directly prove the existence of certain facts, but this evidence is used to make these facts become clearer and more understandable.

Munir continued Fuady ${ }^{20}$ download explain in more detail about demonstrative evidence, which demonstrated pengadil2an in front of a judge. If done outside the court, will be a tool of experimental evidence or a scientific evidence. Demonstrative proof tool is very useful for the judge to get an impression of the actual or apparent from the first hand so that the judge can capture the feel of the real of a legal fact. It's certainly better than just hearing stories from witnesses. This is consistent with what people often say that the new first seen believe "(seeing is believing), in this view the demonstration of the demonstrative evidence.

To a demonstrative evidence can be accepted as evidence, as described in the previous section, the law should require the following matters ${ }^{21}$ :

1. Evidence Must Be Another.

2. Representative accuracy.

3. Authentication.

4. Identification

5. Admissibility.

In the law of evidence are taught that in order for a tool evidence can pass the admission test, the following requirements must be met:

a. relevancy,

b. materiality(significant)and

\footnotetext{
19 Munir Fuady, 2012, Teori Hukum Pembuktian, Citra Aditya Bakti, Bandung. p.191 20 ibid

21 lbid, p 192-193
} 


\section{c. competency,}

Thus, which will be demonstrated in court must be able to prove something relevant, significant, and competent (in accordance with the function of the court, such a polite, did not violate ethics, etc.).

6. To balance (Balancing), demonstrative evidence have positive effects in addition to the negative effects. The most important positive effects of course clarify that would prove it. Thus, an element of probative. The negative effects will lead to misleading, more emotional than rational fishing, wasting time, and others. Therefore, we need a balance, in the sense of minimal positive effect should be balanced or even exceed the negative effects. Otherwise, appropriate demonstrative evidence rejected.

still a lot of other evidence by using physical evidence, both exhibited in court (demonstrative proof) and that just brought to show to the judge in court (real proof). Increasingly, the model more and more. These include the use of hidden camera (wiretaps), records an image, video or sound is hidden to a recording of an image, video or voice, SMS messages via mobile phones, voice mail phone records, photographs, sound recordings fighter pilot in the plane's black box and other physical evidence or modern scientific temper increasingly numerous and sophisticated. Inevitably, the court must be able to receive such evidence as evidence in court, either in civil cases and in criminal cases, with certain restrictions,

Thus, in the science of law of evidence, demonstrative evidence can be allowed into evidence all the aid according to the court evidence is sufficient to explain certain facts or profoundly explained the facts to be proved it. Furthermore, in addition to the relevant facts to be proved, must also be maintained so that the use of demonstrative evidence was not until too prejudice (being a presumption) that it can obscure the real issue. In addition, the 
admissibility by the court, either evidence of real and demonstrative evidence, that evidence of authentication considerations also need to be proven in earnest.

The "determination" of judges on the use of teleconference of the examples of the above cases, merely to be regarded as the efforts to be made by a judge under Article 10 paragraph (1) and Article 5 (1) of Law Number 48 Year 2009 on the Judicial power as a breakthrough in the system proving criminal matters. It may therefore be regarded as the legal construction carried out by quasi legislators caused by the legal vacuum that regulate these technologies. And to strengthen the pillars of the legal framework of law enforcement should be quasi legislator product can be input for forming (legislators) legislation in the future (constituendum juice).

Its mean a legal steps in the event it is not just a matter of procedural, but it should be clear and strict regulation in order to avoid discrimination law and misinterpretation. Moreover, the use of teleconference technology requires a large cost that should be considered with the results to be obtained from the use or utilization of the teleconference technology.

Efforts to harmonize the principle of legality (both in its understanding of aspects of criminal law substantive or formal) and Article 5 (1) and Article 10 paragraph (1) of Law Number 48 Year 2009 concerning Judicial Authority, needs to be realized is not merely rhetorical, so witness testimony conducted or conducted via teleconference with legal force under the criminal case verification system. Because basically no good if a law only contains decisions ad hoc.

Implementation of evidence through electronic media in a criminal act, should the judge may use the priority when it will use the values of the basic purpose of the law (justice, expediency and certainty) to accommodate the evidence through electronic media in examining the crime of existing. 
As it is known that among the three basic values (fairness, expediency and certainty) there is a tension, because of the three values of the legal basis for each make different demands of each other, so that all three have the potential to contradict each other. When taken as an example of legal certainty so as he immediately shifts the value the values of justice and usability laterally. According to Radbruch, as quoted by Satjipto Rahardjo ${ }^{22 " I f}$ there is tension between basic values, we must use the base or the principle of priority in which the first priority is always to fall on the values of justice, the new value of usefulness or expediency and last rule of law. This shows that Radbruch putting the value of justice is more important than the value of the benefit and the value of the rule of law and put the value of legal certainty under the law benefit value.

\section{Closing}

Implementation of evidence through electronic media in a criminal act, can be used everyone in the court proceedings, to the extent deemed necessary by the judges. While a person is not present in court, but because he was already under oath, it can be used as a valid legal instrument. So the witness testimony here is the main evidence. Because someone in committing a crime certainly will try to eliminate his mark, so that in a criminal case, the proof will be focused on the testimony of witnesses.

22 Satjipto Raharjo, Law, Citra Aditya Bakti, Bandung, 2012, p. 32 


\section{Bibliography}

A.J.T, Swindy. (2014) Kesaksian Saksi Melalui Teleconference Dalam Persidangan Pengadilan, Jurnal Lex Ex Societatis, 2 (8).

Djanggih, Hardianto and Kamri Ahmad, (2017) The Effectiveness of Indonesian National Police Function on Banggai Regency Police Investigation (Investigation Case Year 2008-2016, Jurnal Dinamika Hukum, 17(2).

Fuady, Munir (2012) Teori Hukum Pembuktian, Citra Aditya Bakti, Bandung.

Hamdi, Syabatul. et.all, (2013) Bukti Elektronik Dalam Sistem Pembuktian Pidana, Jurnal Ilmu Hukum, 1(4).

Hartono, C.F.G Sunaryati. (1982) Hukum Ekonomi Pembangunan Indonesia, Binacipta, Bandung.

Harahap, M. Yahya. (2006) Pembahasan Permasalahan dan Penerapan KUHAP Pemeriksaan Sidang Pengadilan, Banding, Kasasi, dan Peninjauan Kembali: Edisi Kedua, Sinar Grafika, Jakarta.

Lasmadi, Sahuri (2001) Pengaturan Alat Bukti Dalam Tindak Pidana Dunia Maya, Jurnal IImu Hukum. Naskah Akademik Rancangan UndangUndang tentang Tanda Tangan Elektronik dan Transaksi Elektronik Lembaga Kajian Hukum Teknologi, Fakultas Hukum Universitas Indonesia (lkht-fhui), Depok.

Mamitoho, Refly Aditya. (2014) Penggunaan Alat Bukti Elektronik Dalam Pemeriksaan Perkara Perdata, Jurnal Lex Ex Societatis, 2 (1).

Makarim, Edmon. (2005) Pengantar Hukum Telematika, Jakarta : Raja Grafindo Persada.

Moerad B.M, H. Pontang. (-) Pembentukan Hukum Melalui Putusan Pengadilan Dalam Perkara Pidana, Alumni, Bandung.

Pujirahayu, Esmi Warasih. (2016) Pemikiran Hukum Spiritual Pluralistik, Sisi Lain Hukum yang Terlupakan, Tafa Media, Yogyakarta.

Raharjo, Satjipto (2012) IImu Hukum, Citra Aditya Bakti, Bandung.

Saputra, Daniel. (2015) Peggunaan Alat Bukti Informasi Elektronik Dalam Pembuktian Tindak Pidana Narkotika Di Aceh, Jurnal Dinamika Hukum, 3 (2).

Sitompul, Josua (2012) Cyberspace, Cybercrimes, Cyberlaw : Tinjauan Aspek Hukum Pidana, Tatanusa, Jakarta. 
Sulistiyawati, Putu Elik dan I Ketut Sujana, (2013) Pemanfaatan Telekonfren Sebagai Alat Bukti Bantu Pembuktian Dalam Sistem Peradilan Pidana, Jurnal Kertha Wicara, 2(1).

Takasihaeng, Arbiyanto. (2013) Praktik Peradilan Dalam Penerapan Alat-alat Bukti Menurut KUHAP, Jurnal Lex Crimen, 2(3).

Undang-Undang Nomor 8 Tahun 1981 Tentang Kitab Undang-Undang Hukum Acara Pidana

Yudhistira, et.all, (2012) Kekuatan Surat Elektronik Sebagai Alat Bukti Dalam Persidangan Dintinjau Dari Hukum Acara Pidana, Jurnal Kertha Wicara, 1(1).

Widiastuti, Tri Wahyu. (2009) Peranan Perubahan Sosial Terhadap Macam Alat Bukti Dalam RUU KUHAP, Jurnal Wacana Hukum, 8(1) 